\title{
Digital Branding Model for Jumputan and Songket Fabrics: As a Continuity Strategy for Marketing Palembang Local Products
}

\author{
${ }^{1}$ Business Administration Department, Politeknik Negeri Sriwijaya, Palembang, Indonesia \\ ${ }^{2}$ Accounting Department, Politeknik Negeri Sriwijaya, Palembang, Indonesia \\ ${ }^{3}$ Computing Technique Department, Politeknik Negeri Sriwijaya, Palembang, Indonesia \\ ${ }^{4}$ Business Administration Department, Politeknik Negeri Sriwijaya, Palembang, Indonesia \\ *Corresponding author. Email: djumrianti@ymail.com
}

Desloehal Djumrianti ${ }^{1, *}$ Rita Martini ${ }^{2}$ Ikhtison Mekogga ${ }^{3}$ Alfitriani Alfitriani ${ }^{4}$

\begin{abstract}
The development of internet enables people have opt to do something rather than just conventional ways. In the marketing, for example, the marketers may use the apps or platforms to offer products via online, they also may create the digital branding. In this pandemic era, the marketers must be able to find best strategics to survive. In addition, in the long term, small entrepreneurs such as SMEs of traditional cloth of Palembang, Jumputan and Songket should continue to increase sales both in quantity and quality. Therefore, the aim of the current study was to obtain a suitable model to be used as digital branding for Palembang's Jumputan and Songket. The study also reached several purposes, such as to get the right elements to be used in making digital branding; reflect Jumputan and Songket fabrics digitally; assist craftsmen in preparing brand identity (name of products); help craftsmen build brand awareness; assist craftsmen in creating networks digitally; and help increase sales of Jumputan and Songkets' products during the pandemic and in the long term. A total of 47 people from Palembang's jumputan and songket fabric craftsmen were respondents, and 4 of them became informants in this study. The data was collected through interviews to informants, distributed questionnaires to selected respondents, and documentations. By using reduction techniques to process data, to produce the model pattern of digital branding for the UMKM craftsmen of Palembang's Jumputan and Songket fabrics.
\end{abstract}

Keywords: MSMEs; Jumputan; Songket; digital branding

\section{INTRODUCTION}

Palembang is one of cities in Indonesia that is still attached to its traditions, such as foods; traditional arts; and traditional fabrics. Palembang at least has two famous traditional fabrics, they are Tie Dye or Rainbow or also known as Jumputan because the manufacturing process is by being pinched or tied. Another traditional cloth is Songket, a cloth woven using gold and silver threads with interesting motifs. As Purwanti and Siregar [17] claim previously the Songket was only used for certain events related to customs or official events, such as marriages, awarding titles, and so on. Furthermore, Purwanti and Siregar [17] added based on its history, the Songket was the result of assimilation of Chinese and Indian cultures in the past.
Jumputan and Songket fabrics are still produced in Palembang, there are a lot of craftsmen making and selling these products. There are several areas in this city that have become centers for making Jumputan, such as in Tuan Kentang. Meanwhile, Songket craftsmen are in the Tanggo Buntung area. Based on an interview with Lurah, the village head of Tuan Kentang, Kertapati Palembang District (November 2020) in this area there are around 90 Micro, Small and Medium Enterprises (MSMEs) who are produce and sell Jumputan. Meanwhile, there are around 50 songket craftsmen in Tanggo Buntung [21]. Based on the results of interviews with cultural historians and cultural observers of Palembang art (Panji and Al-Lintani, August 12, 2021) there are approximately 46 motifs of Palembang Songket. However, there are around ten motifs of songket that popular among people, such as lepus nampan peral, lepus 
naga besaung, bunga pacar, lepus berantai, biji pare, cantik manis, kembang tabur, bunga cina, bunga jatuh, and kembang pulir[13]. While the types of motifs from jumputan fabrics include seven-spotted motifs, leaf flowers, five spots, nine spots, cuncung (eggplant), five stars, and spots [15][16].

The motifs and types of Songket and Jumputan have been passed down from generation to generation for years. Based on the history, the motifs of Jumputan have existed since the Sriwijaya Kingdom which were brought from Javanese culture. In Javanese culture, the Jumputan cloth is known as 'Cinde cloth'. This cloth was used to carry or as a complement to Javanese dances. At that time there was a cloth "Sumatra and Java known for their silk patola cloth" along with the entry of "silk cloth and threads imported from China in the 7th to 8th centuries", which is considered the emergence of jumputan art [15].

Likewise, historically, Songket has been around for a long time since the Sriwijaya era around the 13th15 th centuries. Songket was the clothing of the nobles of Sriwijaya at that time. The motifs and types of Songket that exist today are inherited from the ancestors who produced songket during the Sriwijaya era.

So it can be concluded that these two traditional Palembang fabrics, both motifs and types, are well known by themselves because of the existence of these fabrics for a long time. Although it has been known for quite a long time, there is no segmentation and characteristics of each craftsman (maker of Songket and Jumputan cloth).

Buyers know the two fabrics not because of the identity attached to each of these products but lies in the motifs, types, colors, quality and prices which are very similar from one craftsman to another. The prices offered for the two products are also not much different from one craftsman to another, for example, the price of 1 set of Songket is between Rp. 600,000-15,000,000, while 1 piece of Jumputan cloth with a size of $3 \mathrm{~m}$ ranges from Rp. 200,000-800,000 [4]. The spreading of these fabrics are by three ways, first from worth of mouth, buyers usually know of these Palembang fabrics were by word of mouth and some craftsmen who market their products online. Second, consignment based on an interview with a Jumputan craftsmen, he usually out the products to the 16 Ilir market or the Wong Kito market (with an agreement that if the products cannot be sold in stipulated time, they will be returned to the craftsmen). Third, buyers who come directly to their place either in large parties or in small bulk. In one month around 30-100 pieces of cloth can be sold [4]. Meanwhile, there are fewer buyers of Songket because the price is quite expensive, around 2-20 sets per month. The market share of this product also varies from 20-60 years old [4].

Therefore, there are no trademarks based on the specific product identity of each craftsman and there are no characteristics that are highlighted from Jumputan and Songket fabrics both conventionally and digitally. The development of internet and communication technology has not been utilised in the branding of Jumputan and Songket fabrics. This phenomenon has prompted this research to be carried out, besides that there has been no research to date that has raised digital branding for typical Palembang fabrics, especially Jumputan and Songket fabrics.

\section{LITERATURE REVIEW}

\subsection{Branding is a communication strategy}

Communication is very important in every marketing activity. Branding strategy is a form of marketing communication that emphasises on the brand of a product. The form of brand communication is the first step for a product to introduce and to develop in the community [19].

According to marketing experts [6][22][7] branding could be a name, slogan, sign, symbol or design, or a combination of these elements, that distinguish one company, product, or service from another. Thus, it is clear enough that communication between buyers and sellers or in this study craftsmen should convey name of products combination with other elements as the identity of the product, which is the seller's way of conveying a message to the buyers.

The delivering of messages through those elements is the way of direct or indirect communications by seller in conveying the product itself. Rooney (1995) emphasises that branding will never die, branding is a trend for today and tomorrow. As social beings, communication will continue to be carried out by humans both as sellers and as buyers. So that branding will remain a trend and is needed every time in communicating with buyers.

Agreeing with Rooney (1995) a group of scholars Martin [9] asserts that "a brand name is among the most fundamental and long-lasting assets of a firm". Thus, branding is indeed, important, and fundamental or as an asset of the company. Many marketers think that increasing the value of branding can improve the quality of communication that will be built through branding itself to buyers or competitors [9]. Therefore, building and improving branding should not be taken lightly for a company or another. 


\subsection{What is brand building?}

As explained earlier, branding can be in the form of anything such as logos, symbols, jargon, websites and so on. Meanwhile, building branding is a process of creating value to consumers. It implies all things that consumers know, feel, and experience about your business in its entirety. Gregogry (2020) also said that the brand is to generate awareness about a business using strategies and campaigns with the goal of creating a unique and lasting image in the marketplace. However, here he emphasises that brand building is more about how to build awareness of a business by creating something unique and memorable for the market. Furthermore, Gregory (2020) notes that through the brand, customers can assess the overall business. Meanwhile, Negoita et al (2015) focus on the process of designing logos, slogans and so on from a product.

Meanwhile, a group of scholars Judson et al (2008) claim that a branding can be built from within and outside a company, it could be through company leaders and employees, how do they perceive a product. They further emphasised that internal branding can be in the form of (1) identification of the source of the product, (2) assignment of responsibility to product markers, (3) risk reducer, (4) search cost reducer, (5) promise, bond, or pact with maker of product, (6) symbolic device, and (7) signal of quality (Keller in Judson et al, 2008). Internally, the company only needs to choose from the seven elements above or all of them can be used in building internal branding. Emotionally tentative conclusions that internal branding can also make it possible that instilling a sense of pride in the product and the company they work for in the company's employees can even increase job satisfaction [5].

On the other hand, they also said that external branding "simplifies a consumer's decision process through advertising and a strong brand promise, corporations have recognized the value of promoting the brand message internally as well" [5]. Submission of messages that can affect the purchase decision of a product. So, brand building is an important thing that every business must do because it can have an overall impact on a company. With a good brand building, the face that the company builds will also be good.

\subsection{Digital Branding}

Conventionally, branding can be built manually in the form of logos, symbols, and so on. But technological advances have helped marketers reach a wider audience, for example using the internet in creating digital branding. Many famous logos or names often appear in several media on the internet, so that they get a positioning in the minds of a wider customer. Even the rapid use of social media has recently resulted in Ballouli and Hutchinson (2010) conclude the social media can help athletes, artists, and celebrities build their brands through this medium. This strategy is considered effective in reaching the right and fast target market.

In addition, Lipiäinen and Karjaluoto (2015) emphasise that digital marketing is a strategy and tactic that can be used by Business to Business (B2B) and Business to Customer (B2C) business people, by studying the characteristics of target customers and products that will be dynamically branded, and changing, evolving as needed digitally through electronic media. So it's just business people who adjust to what will be branded digitally and what target customers will be achieved (Lipiäinen and Karjaluoto, 2015). However, Christodoulides and De Chernatony [3] assert that any form of branding, both conventional and digital, must have a fixed template that is consistent and original. So in other words, even though branding is done digitally, it is still consistent and does not manipulate products with today's technological advances. The principle of branding is to increase the value of the product itself. So there are several points in the concept of digital branding that might be done, such as: 1) directly between the brand and its stakeholders; 2) indirectly in the relationship between the internal and external stakeholders; 3) in the interactions among the various network actors, and also 4) through the themes in which the brand is connected [3]. So, branding must include delivering branding internally, externally, and positioning the brand in relevant conversations to the target market to be addressed.

\subsection{Digital branding and market potential}

As the previous description, it is clear that potential online market is very large. The purpose of digital marketing is to encourage and motivate buyers or prospective buyers from being able to make purchasing decisions for goods or services. The development of internet technology, especially the rapid development of the use of social media lately to market and sell products, has opened and formed an extraordinary market. The target market can be reached more broadly [1] so, that turnover in quantity and rupiah can be more optimal. The facilities offered by the internet and the culture of using social media, such as mobile phone, where users directly or indirectly have been opened up the widest opportunities for marketers to take advantage of this opportunity. In addition, the culture of the world 
community that uses social media a lot is also a large market that must be exploited. Designers and marketers must be able to encourage loyal customers and potential customers to proceed to the next step, namely the decision to buy the products offered. The experience of surfing in cyberspace, including shopping, will provide a unique opportunity for them to gain experience in the online market.

\section{METHODOLOGY}

\subsection{Location and time}

The research was carried out in Palembang in two places of Palembang's Jumputan and Songket fabric craftsmen, namely in the Tuan Kentang area, Kertapati and in Tangga Buntung Palembang. The research was conducted for 6 months from May - November 2021.

\subsection{Objects of Research}

There were two MSMEs craftsmen as the objects of research, Jumputan, namely Salsabila 091 which located in the area of Tuan Kentang, Kertapati Palembang; and another MSME of Songket craftsman, namely Rumah Limas Songket which located in the Tangga Buntung area of Palembang. The reason for choosing these objects because they were the makers and sellers of Palembang of Jumputan and Songket.

\subsection{Population and Sample}

Population generalise as area consisting of objects or subjects that have certain qualities and characteristics determined by researchers to be studied and then drawn conclusions. To get some important data for this current research, it is also necessary from visitors or audiences or individual buyers of Jumputan and Songket fabric products in these two MSMEs. From 2018-2020 the visitors of Salsabila 091 582; 667; 207, total was 1,456 . While, the visitors who came to the Rumah Limas Palembang in the last three years; 678; 706; 411, total was 1,795 (Rumah Limas Palembang, 2021). Thus, the population of this study around 3,251 visitors from SMEs of Palembang's Jumputan and Songket fabric craftsmen.

While sample selected by using accidental sampling technique. Sugiyono (2016: 85) notes "accidental sampling is a sampling technique based on chance, that is, anyone who coincidentally meets a researcher can be used as a sample, and if it is deemed that the person who happened to be met is suitable as a data source". Therefore, by using the Slovin sampling technique, where: $\mathrm{n}=$ minimum sample size $\mathrm{N}=$ population size e $=$ inaccuracy tolerance due to sampling error. The total population in this study was 3,251 visitors so that the tolerance for inaccuracy due to sampling errors that the researchers determined was $10 \%$ and the results of the calculations could be rounded off to achieve conformity. So, it was around 97 respondents, divided into two or as many as 49 respondents in Salsabila 091 the remaining 48 respondents for Rumah Limas Palembang.

\subsection{Data collection techniques}

To obtain the data needed in this study, the researchers used several methods as follows: (1) Interview, in this current study, the researchers conducted semi-structured interviews to 6 informants in the Tuan Kentang area, namely the owner, workers (makers of Jumputan and Songket fabrics); Lurah (Village Head) of Tuan Kentang; art historian. (2) Questionnaire, several questionnaires were distributed directly to 97 respondents who were selected in the textile village industry in Tuan Kentang and in the Tangga Buntung area to explore the desired data. (3) Documentation, this study used documentation in the form of photographs of the general condition of the textile village industrial center in Tuan Kentang and the Tangga Buntung area. Researchers also obtained data from the Palembang City Tourism Office, Palembang City Industry Office. (4). Some references which related to theoretical studies and other references related to values, culture and norms that develop in the social situation being studied, besides that library studies are very important in conducting research, this is because research does not will be separated from the scientific literature. Data obtained from data relevant to the problem to be studied by conducting other literature studies such as books, journals, articles, previous researchers.

\subsection{Data Analysis Techniques}

There were two techniques that used, first to analyse the data obtained from interviews and questionnaires, by using reduction. It will used a design engineering approach for website creation, names, symbols of Jumputan and Songket products produced by MSMEs Tuan Kentang and Rumah Limas Songket. The first data analysis technique in this study was started with data reduction, the researchers reduce data that is considered unrelated or irrelevant to the formulation of the problem and the objectives of the study. There are several steps taken in this study, namely 1) Reading and re-reading; 2) Initial notes; 3) Developing Emergent themes; 4) Searching for connections across emergent themes; 5) Moving the next case; and 6) Looking for 
patterns across cases [10]. Reading and re-reading in this stage the researcher will read the data from the interviews and interviews in depth. Imagining the words of the participants when they were read and reread by the researcher from the transcript would help a more complete analysis. This stage was carried out to provide confidence that the research participants were really the focus of the analysis. The researcher started this process with the assumption that each participant's words were very important to enter the analysis phase and that the data of the words were treated actively. Re-reading the data with the overall model of the interview structure for further development, and also providing the opportunity for researchers to gain an understanding of how participant narratives can be divided into several parts. Reading and rereading also makes it easier to assess how relationships and trust are built between interviews and then bring out the locations of richer and more detailed passages or actual contradictions and paradoxes. Thus, in this study the results of interviews and questionnaires that have been made in the form of transcripts.

While, initial noting examined the content of the words, sentences and language used by participants at the exploratory level. This analysis maintains an open mind and records anything interesting in the transcript. This process fosters and creates a more familiar attitude towards the transcription of data. In addition, this stage also begins to identify specifically the ways in which participants say something, understand and think about issues. Stages 1 and 2 merge, in practice starting with making notes on the transcript. The researcher starts the activity by reading, then makes exploratory notes or general notes that can be added to the next reading. This analysis is almost the same as free textual analysis. Here, there is no rule whether commented on or without conditions such as dividing the text into units of meaning and giving comments on each unit. This analysis was carried out with the aim of producing a comprehensive and detailed set of notes and comments on the data. Some parts of the interview contain more research data than others and will provide more meaning and commentary. At this stage, begin to comment by guessing on what is in the text. The description that the researcher developed through these initial notes became the core description of the comments which was clearly the focus of phenomenology and very close to the explicit meaning of the participants. This includes looking at the digital branding model desired by the craftsmen, by identifying the initial concepts of digital branding. This helps researchers create awareness of patterns of meaning in the statements of informants and respondents. The original data from the transcripts were provided with comments using exploratory comment illustrations. Exploratory comments were carried out to get the gist. Exploratory comments include descriptive comments, language comments (linguistic comments) which are carried out simultaneously. Descriptive comments are focused on describing the content of what was said by the respondent and the subject of the words in the transcript. Language commentary is focused on exploratory notes that pay attention to the use of specific content by the informant or respondent. Researchers focus on the content and meaning as well as what message will be conveyed. This conceptual commentary is more interpretive focused on the conceptual level. This conceptual coding uses interrogative forms (questioning).

Developing emerging themes, the initial notes, is more than just a transcript. The comprehensive exploratory commentary is very close to the conclusion of the original transcript. In the research, themes and coding will be carried out as one of the appropriate techniques to analyse qualitative research. As Neuman (2006) claims the 'Themes and Coding' technique was useful for interpreting what is obtained from field research. So that this research will be carried out, namely data obtained from interviews, and FGDs will be grouped into several themes and codes. Likewise, data obtained from observations will also be carried out in the same way with the same theme and code. The coding technique used is open coding, where researchers will group or define themes and codes based on what is the most common during field research [12]. This determination was made at the beginning after field research was carried out. The next step is searching for connection a cross emergent themes. At this stage the analysis will be carried out by looking for relationships between emerging themes that have been sorted chronologically. The relationship between these themes is developed in the form of graphs or mapping and thinking about themes that are compatible with each other. This level of analysis has no official provisions that apply. Researchers are encouraged to explore and introduce something new from the results of their research in terms of organizing analysis. Not all emerging themes should be combined in this analysis phase, some themes may be discarded. This analysis depends on the overall research question and the scope of the research. Therefore, the fifth stage the transcripts and questionnaire results, by repeating the same process.

While the last stage was looking for patterns across cases which emergence between cases/participants. The relationship between the cases and how the themes. At this stage a master table was 
made of the themes for forms of communication as outlined in the types of daily conversations used by craftsmen in designing digital branding according to their wishes.

In addition, this study uses a design approach in the form of an example website that can be used as a template for MSMEs for Jumputan and Songket craftsmen. Two websites have been designed which content photos, names of products, brief company profile, brief history of Jumputan and Songket.

\section{RESULTS AND DISCUSSIONS}

\subsection{Digital Branding Based on the Name of Products}

As mentioned earlier, name of products is one of the identity of products itself. Thus, it is important to declare and to introduce each name of the Jumputan or Songket. Based on questionnaires that have been distributed to selected respondents. The results showed that most of the buyers of Jumputan were ladies with the age 28 or above. They came from universities students, household wives, or employees. They were only from Palembang or other cities in South Sumatera but they also came from other provinces in Indonesia and neighbour countries like Malaysia. They used this traditional fabrics for occasional events, parties dresses, special event uniform, or for office grooming. Most of them were from middle class of societies. The buyers mostly bought the Jumputan without asking the name of products, neither the sellers nor craftsmen explain the name of products. They select the products based on the colours, prices, and the size of each pack of Jumputan.

However, the study disclosed that the buyers, sellers, or craftsmen required the name of products. Based on the themes and codes, there were around fourteen categories of the reasons why the name of products were needed for them. The table 4.1 below showed the percentages of feedback from selected respondents,

Table 1 Themes why the name of Jumputan as branding of Traditional fabric of Palembang

\begin{tabular}{|c|l|c|}
\hline $\begin{array}{c}\mathbf{N} \\
\mathbf{o .}\end{array}$ & \multicolumn{1}{|c|}{ Themes } & $\begin{array}{c}\text { Percentages } \\
(\mathbf{\%})\end{array}$ \\
\hline 1. & $\begin{array}{l}\text { Harmonisation between the } \\
\text { name and Jumputan fabrics }\end{array}$ & 62 \\
\hline 2. & $\begin{array}{l}\text { Given different names } \\
\text { based on the type of } \\
\text { fabrics offered }\end{array}$ & 58 \\
\hline
\end{tabular}

\begin{tabular}{|c|c|c|}
\hline 3. & $\begin{array}{l}\text { The name of products } \\
\text { encourage buyers willing } \\
\text { to buy }\end{array}$ & 72 \\
\hline 4. & $\begin{array}{l}\text { The name of each product } \\
\text { motivate consumers to } \\
\text { know more about the } \\
\text { background of the name }\end{array}$ & 66 \\
\hline 5. & $\begin{array}{l}\text { There were new products } \\
\text { generated from innovation } \\
\text { of previous products }\end{array}$ & 73 \\
\hline 6. & $\begin{array}{l}\text { The name of each } \\
\text { Jumputan clothes for the } \\
\text { long terms }\end{array}$ & 59 \\
\hline 7. & $\begin{array}{l}\text { The name of Jumputan } \\
\text { from Salsabila } 091 \text { able to } \\
\text { find online }\end{array}$ & 82 \\
\hline 8. & $\begin{array}{l}\text { The name of Salsabila's } \\
\text { products was on the } \\
\text { internet and is appropriate }\end{array}$ & 77 \\
\hline 9. & $\begin{array}{l}\text { Each product produced by } \\
\text { Salsabila } 091 \text { has its own } \\
\text { uniqueness }\end{array}$ & 75 \\
\hline 10 & $\begin{array}{l}\text { Salsabilas' products with } \\
\text { their names and } \\
\text { characteristics are more } \\
\text { prominent than products } \\
\text { from other similar } \\
\text { craftsmen }\end{array}$ & 65 \\
\hline 11 & $\begin{array}{l}\text { Consistent use of the } \\
\text { names of Jumputan fabric } \\
\text { products so far }\end{array}$ & 73 \\
\hline 12 & $\begin{array}{l}\text { Not influenced by 'tye die' } \\
\text { products from other } \\
\text { regions that are now } \\
\text { popular }\end{array}$ & 84 \\
\hline $\begin{array}{l}13 \\
.\end{array}$ & $\begin{array}{l}\text { The use of words that are } \\
\text { simple and easy to } \\
\text { understand in naming } \\
\text { Jumputan fabric products }\end{array}$ & 69 \\
\hline 14 & $\begin{array}{l}\text { The use of regional names } \\
\text { as markers of the origin of } \\
\text { the Salsabila's } 091 \\
\text { products }\end{array}$ & 74 \\
\hline
\end{tabular}

Source: data processing, 2021

As shown on the table 4.1 above most of respondents agree that the name of products were required to give the identity of products itself. The Jumputan fabrics made in Salsabila 091 were unique and different with other similar products, such as 'tye dire' from Java, Indian, or Africa. The colours and motifs were characterised the products as only produced by Salsabila 091. This indicates that the customers know the differences between Salsabila's products and others. The 
use of regional names, such as Palembang on the name of product was add the value of Jumputan itself. Buyers or customers more confidents that the products produced in Palembang and willing to buy the products. As Lake (2021) believes branding means not only deliver a message to potential customers but it has been confirms that "the brand's cre credibility in the marketplace, emotionally connect target prospects with a product or service, motivate the buyer to make a purchase, and create user loyalty".

The use of social media, such as Instagram and facebook to introduce the products was a way of Salsabila 091 to spreading the Jumputan online. Although the products rarely up-dated on these social media, around 80 percentages of respondents agree the products were able to find online. The facilities of internet enabled potential customers to take a look the products before decide to buy. The social media was initial way to let people know products of Salsabila 091 through online. Indirectly that also the way of them brand the product digital. Based on the interview to the Lurah of Tuan Kentang, she agreed that the use of internet has been facilitated the craftsmen introducing their products.

However, according to the Cultural Expert (Panji, 2021) sometimes the Jumputan craftsmen ignore the precise name of the products. They have a lot of similarities motifs and colours with others. Thus, the craftsmen in Tuan Kentang area almost do not have privilege compare to others. Therefore, even though they offer the products online, it has not much different with conventional ways. The most important thing the craftsmen have consistent use the name of products whether offer offline or online.

While, a unique argument come from Rowles (2014), he asserts that on the one hand technological advances have helped many marketers in designing unique and attractive branding. But on the other hand Rowley countered his own statement that internet technology, for example, has made branding competition more and more difficult to control the market. This technology has made it easier and even indulgent for marketers to design, modify and update branding without compromise.

At a different case, the Songket was produced by Rumah Limas Songket Palembang, it also a traditional fabric of Palembang. The products that creation of this MSME normally sell to middle social societies or above. So that is why they create products only one or two pieces for each models and motifs. The table 4.2 below shows the percentages of the themes for Songkets' name as the brand identity of traditional fabric of Palembang.

Table 2. Themes why the name of Songket as branding of Traditional fabric of Palembang

\begin{tabular}{|c|c|c|}
\hline No. & Themes & $\begin{array}{c}\text { Percentages } \\
(\%)\end{array}$ \\
\hline 1. & $\begin{array}{l}\text { Harmonisation between the } \\
\text { name and Songket fabrics }\end{array}$ & 57 \\
\hline 2. & $\begin{array}{l}\text { Given different names based } \\
\text { on the type of fabrics offered }\end{array}$ & 62 \\
\hline 3. & $\begin{array}{l}\text { The name of products } \\
\text { encourage buyers willing to } \\
\text { buy }\end{array}$ & 70 \\
\hline 4. & $\begin{array}{l}\text { The name of each product } \\
\text { motivate consumers to know } \\
\text { more about the background of } \\
\text { the name }\end{array}$ & 58 \\
\hline 5. & $\begin{array}{l}\text { There were new products } \\
\text { generated from innovation of } \\
\text { previous products }\end{array}$ & 75 \\
\hline 6. & $\begin{array}{l}\text { The name of each Songket } \\
\text { fabric for the long terms }\end{array}$ & 64 \\
\hline 7. & $\begin{array}{l}\text { The name of Songket from } \\
\text { Rumah Limas Palembang } \\
\text { able to find online }\end{array}$ & 77 \\
\hline 8. & $\begin{array}{l}\text { The name of Rumah Limas } \\
\text { products are on the internet } \\
\text { and is appropriate }\end{array}$ & 79 \\
\hline 9. & $\begin{array}{l}\text { Each product produced by } \\
\text { Rumah Limas has its own } \\
\text { uniqueness }\end{array}$ & 72 \\
\hline 10. & $\begin{array}{l}\text { Rumah Limass' products with } \\
\text { their names and } \\
\text { characteristics are more } \\
\text { prominent than products from } \\
\text { other similar craftsmen }\end{array}$ & 66 \\
\hline 11. & $\begin{array}{l}\text { Consistent use of the names } \\
\text { of Songket fabric products so } \\
\text { far }\end{array}$ & 73 \\
\hline 12. & $\begin{array}{l}\text { Not influenced by 'songket' } \\
\text { products from other regions } \\
\text { that are now popular }\end{array}$ & 60 \\
\hline 13. & $\begin{array}{l}\text { The use of words that are } \\
\text { simple and easy to understand } \\
\text { in naming Songket fabric } \\
\text { products }\end{array}$ & 67 \\
\hline 14. & $\begin{array}{l}\text { The use of regional names as } \\
\text { markers of the origin of the } \\
\text { Songkets products of Rumah } \\
\text { Limas }\end{array}$ & 72 \\
\hline
\end{tabular}

Source: data processing, 2021

Similarly with Jumputan produced by Salsabila 091, the Songket created by Rumah Limas Palembang also need the name as the brand identity. As the table 4.2 
above more than half of selected respondents agrees that the precise name of products were required to introduce them in the broader markets. This not only for local market but also for overseas market. The use of social media to introduce the products of Rumah Limas Palembang has been preliminary strategy to brand their products. Rumah Limas Palembang uses the Instagram to offer their products.

As the traditional product of Indonesia, Songket Palembang is not the only one traditional fabrics. At least Pontianak's Songket is one of fabric which is very similar with the Palembang's Songket. In Malaysia we also my find the similar fabric. So, there were around 72 percentages of respondents agree that the name of 'Palembang' - was indicated the city of the Songket produced.

Similarly with the Jumputan, the Cultural Expert (Panji, 2021) also emphasises that the most important not the way how the Songket will introduced or brand but the consistency of using the name for long time. Therefore, whether the Songket will be stamp on digital brand of conventional digital the craftsmen should pay attention to the concept of name itself.

\subsection{Websites as the Media for Digital Branding}

Despite of both issues, the need of introducing the name of products in the larger markets were important to market the products. The use of social media were not coverage enough to reach the broader markets. Therefore, the study also produced two websites for Salsabila 091 and Rumah Limas Palembang to let them branding their products through the websites. The websites were in Indonesia and will be designed in English if there is a required form craftsmen or sellers. The figure 4.1 below is one of the Website has been designed.

\section{RUMAH LIMAS}

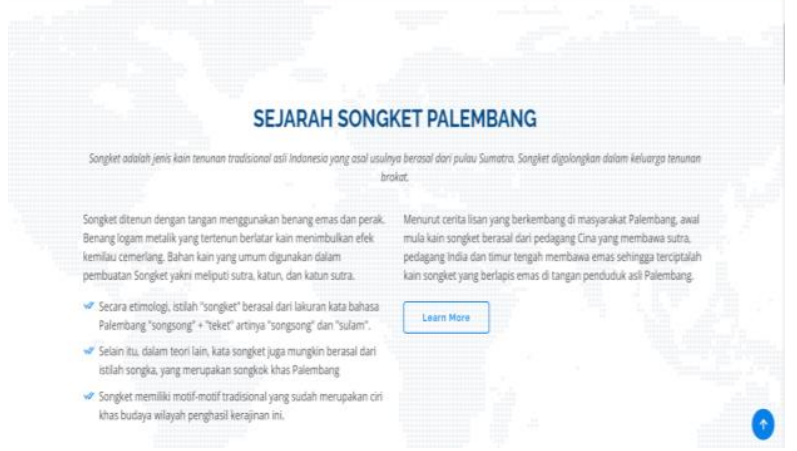

RUMAH LIMAS

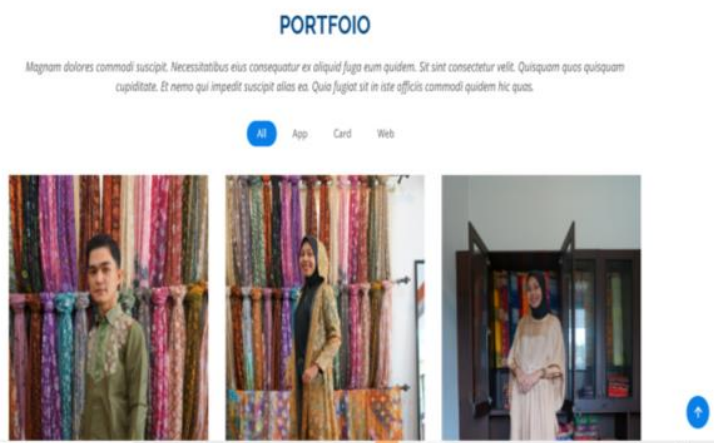

Figure 1 Sample of Rumah Limas Website's Pages

The figure 4.1 is the sample of pages on the websites of Rumah Limas Palembang. To construct the branding digital the website was not only designed as commercial website but also education website. In the website people may learn the history of Songket, so, they may interesting to know more about the product before making a decision to buy. As Ballouli and Hutchinson (2010) concluded that online media can help many people build their brands through this medium. This strategy is considered effective in reaching the right and fast target market. In addition, Lipiäinen and Karjaluoto (2015) emphasise that digital marketing through the online media, such as website is a strategy and tactic that can be used by Business to Business (B2B) and Business to Customer (B2C) business people, digitally through electronic media. So it's just a matter of business people adjusting to what will be branded digitally and what target customers will be achieved.

\section{CONCLUSION}

The name of product is one of the way to brand of traditional products of Palembang. This not only to introduce each product to potential market but also as the identity of product itself. The similarities of products which produced by Salsabila 091 - Jumputan with other products whether produced by locals or other nations was the main issue why the name of Jumputan was required to create. This also imply to Songket, there were a few regions in Indonesia also produce similar products. The actualisation of originality product through the name and place of producing were also needed.

The issue of unsuccessful using previous social media to introduce and branding products was another issue has been solve in this current study. The study offered two websites which were combination between commercial and education to let potential customer learn more before purchasing the products. 
The websites is one of the media which capable to brand the traditional fabrics of Palembang broader. They able to reach market larger than conventional way of using media - Instagram or facebook. The websites also provide more space for craftsmen or sellers to update or re-create the contents.

Hence, the study disclosed fourteen tactics to produce the name of products which can be used to any product. The website which provides and educates potential buyers was one of the way to introduce the brand and attract them to explore more detail about products. This may lead them to take a decision of buying. The next study will be focus on the characteristic of branding both traditional fabrics of Palembang.

\section{REFERENCES}

[1] Anna, K. L. 2018. No size of fashion products were the most popular in online shops. Kompas.com. [Online] from https://lifestyle.kompas.com/read/2018/02/20/15 3826820/produk-fashion-tanpa-ukuran-palinglaris-di-toko-online (akses 11 Maret 2021).

[2] Ballouli, K. and Hutchinson, M., 2010. Digitalbranding and social-media strategies for professional athletes, sports teams, and leagues: An interview with Digital Royalty's Amy Martin. International journal of sport communication, 3(4). pp. 395-401.

[3] Christodoulides, G. and De Chernatony, L., 2004. Dimensionalising on-and offline brands' composite equity. Journal of product \& brand management, 13 (3).pp. 168-179.

[4] JS Collection. 2020. Harga dan penjualan kain. Informal interviews.

[5] Judson, K.M., Aurand, T.W., Gorchels, L. and Gordon, G.L., 2008. Building a university brand from within: University administrators' perspectives of internal branding. Services Marketing Quarterly, 30(1). pp. 54-68.

[6] Kotler, P., 2012. Kotler on marketing. Simon and Schuster.

[7] Lake, L. 2021. Why branding is important in marketing. The balance small business. [Online] dari https://www.thebalancesmb.com/why-is-brandingimportant-when-it-comes-to-your-marketing2294845 (akses 4 Maret 2021).
[8] Lurah Kelurahan Tuan Kentang, Kecamatan Kertapati Palembang. 2020. Total of traditional fabrics in Jumlah pengrajin kain tradisional Palembang di Tuan Kentang. Wawancara informal.

[9] Martin, M.I., Stewart, D, and Matta, S, (2005). Branding strategies, marketing communication, and perceived brand meaning: the transfer of purposive, goal-oriented brand meaning to brand extensions. Journal of the Academy of Marketing Science. 3(3). pp. 275-94.

[10] Mezmir, A. E, 2020. Qualitative Data Analysis: An Overview of Data Reduction, Data Display and Interpretation. Research on Humanities and Social Sciences. 10 (21). pp. 15-27.

[11] Negoita, O.I., Negoita, O.D., Ghituleasa, C. and Purcarea, A.A., 2015. Branding process-An important factor in guiding the company towards success/Procesul de branding-Factor important în orientarea companiei catre succes. Industria textila, 66(2), p.103.

[12] Neuman, W. L. 2020. Social Research Methods: Qualitative and Quantitave. Pearson.

[13] Nisyah dan Nurrosikin, A. 2020. Variety motifs and types of Songket Palembang. Sripokuwiki.com. [Online] from https://sripowiki.tribunnews.com/2020/03/02/ragammotif-dan-jenis-jenis-songket-khas-

palembang? page =3 (akses 2 Maret 2021).

[15] Nurhayati, N., 2018. Preserving culture and art of Jumputan Palembang. Kalpataru: Jurnal Sejarah dan Pembelajaran Sejarah, 2(1), pp.10-15.

[16] Panji, A dan Al-Lintani, V. 2021. Motif and types of Songket and Jumputan Palembang. Informal intervews.

[17] Purwanti, R. dan Siregar, S. M. 2016. History of Songket based on Archeologic Data. Jurnal Arkeologi Siddhayātra. 2 (2). pp 97-106.

[18] Rooney, J.A., 1995. Branding: a trend for today and tomorrow. Journal of product \& brand management.

[19] Rosilawati, Y. (2014). Employee Branding Sebagai Strategi Komunikasi Organisasi Untuk Mengkomunikasikan Citra Merek (Brandimage). Jurnal Ilmu Komunikasi, 6(3). pp. 153-161. 
[20] Rowles, D. 2014. Digital branding: a complete stepby-step guide to strategy, tactics and measurement. Kogan Page Publishers.

[21] Ubaidillah, A. 2020. UMKM Songket Binaan Pertamina Berdayakan Wanita dan Anak Putus Sekolah. Detikfinance. 15 Desember 2020. [Online] dari https://finance.detik.com/berita-ekonomibisnis/d-5296507/umkm-songket-binaan-pertaminaberdayakan-wanita--anak-putus-sekolah (akses 2 Maret 2021).

[22] Vaid, H. and Campbell, A., 2003. Branding. Watson-Gupti 